\title{
Refugee Employment Prohibition in Indonesia
}

\author{
Luthvi Febryka Nola ${ }^{1}$ \\ \{febi_80@yahoo.com\} \\ ${ }^{1}$ Center for Research of the Indonesian House of Representatives, Indonesia
}

\begin{abstract}
In Indonesia, the Immigration and the employment regulations prohibit the refugees from working. Meanwhile, the aids which are given to them are very limited. As a result, the refugees have difficulty to fulfill their needs. This condition makes the refugees work secretly and even commit criminal acts. This paper will examine the weaknesses of the rules prohibiting refugees from working and its solutions. The study was conducted in a normative legal research through library studies to obtain the secondary data which are analyzed with qualitative descriptive. Based on the results, this study found regulatory gaps in the field of the immigration and the employment that can be used by the refugees to work through informal employment schemes, apprenticeship and partnerships. The problem with these various schemes is very limited protections, both for the refugees and the employers. Therefore, the improvements and the arrangements need to be made by opening the employment opportunities for the refugees through a number of restrictions. These restrictions are related to the position and field of work that can be carried out by the refugees and the need for the local labor. The important restrictions are made to protect national interests, namely the availability of employment for the local workers.
\end{abstract}

Keywords: refugees, right to work, prohibition, ratification, the national interest

\section{Introduction}

Referring to Article 4 of the 1945 Constitution, one of Indonesia's goals as a country is creating world peace. To do so, Indonesia has actively participated in global cooperation, one of which is handling refugees. The Global Refugee Forum (GRF) is one of the international forums attended by Indonesia and initiated by the United Nations High Commissioner for Refugees (UNHCR). Here, various countries share their experiences in handling refugees. At the GRF meeting on December 17, 2019, for example, the Indonesian representative, Meutya Hafid (The Chairwoman of Commission 1 in the Indonesian House of Representatives) emphasized Indonesia's commitment to dealing with refugees and the significant role of parliament in promoting global refugee governance [1].

The world is witnessing the large number of refugees which keep growing year to year along with the increasing number of conflicts in different countries. In fact, the policy direction on resettlement countries reduces refugee numbers due to the rise of terrorism and domestic economic issues as it has happened in Australia and the United States. This condition causes international pressure on transit countries like Indonesia which consequently becomes a country party by ratifying the 1951 Refugee Convention and the 1967 Protocol concerning refugee status [2]. At different meeting forums, UNHCR has requested Indonesia to sign the convention and protocol. The country has repeatedly stated its commitment to remain as a transit country despite the pressure. 
The Indonesian government responds to the international pressure on handling refugees by promulgating the Presidential Regulation No. 125/2016 on Handling Offshore Refugees (Presidential Regulation No. 125/2016). Refugees as mentioned in Article 1 Paragraph 1 of the Presidential Regulation are "foreigners who reside and seek asylum in Indonesia due to reasonable fears; grounds of persecution including race, religion, nationality, membership of certain social groups, different political opinions, and unwillingness to get protection from their home country and/or circumstance of gaining a status as asylum seekers or refugees from the United Nations (UN) through the High Commissioner for Refugees in Indonesia". The regulation presents a broader meaning of refugees as it includes asylum seekers as refugees. This is in contrast to UNHCR's opinion, refugees and asylum seekers are different. Such broader meaning, in turn, extends the scope of refugee protection.

Unfortunately, the Presidential Regulation is not supported with budgeting rules which consequently causes the refugee budget to be very limited and unable to support many refugees. The assistance provided by UNHCR is also limited and occasionally leads to an issue considering not all refugees get the same treatment, such as allowance. In the end, it brings a commotion; refugee protest at the UNHCR office and fights among refugee members, among others.

In the meantime, refugees also face some problems ranging from shelter, health services and education for children. Some even live on sidewalks, experiencing limited clean water and food. Some even beg for meals from the surrounding population. A number of retention houses also overlap due to the higher numbers of refugees to accommodate. In fact, the houses are not only used to accommodate them. Things get worsened by the policy that they are banned from having a job or working. Consequently, such conditions, particularly the employment prohibition and psychological issues due to the employment uncertainty in the country of asylum, cause a number of refugees to violate laws; prostitution, adultery, theft and narcotics, among others. 36 refugees in Makassar, for example, are detained in the Immigration Detention Center (Rumah Detensi Imigrasi/Rudenim) for they were involved in sexual harassment, fighting and theft [3].

The high international demand for Indonesia to ratify a convention and the rise of issues on refugees has the potential to disrupt the peaceful society. To that end, a study on refugee regulations, especially the rights of refugees to work in Indonesia, is an interesting topic. The study here is different from other studies that tend to deal with the rights of refugees in general. It will focus on the right of refugees to work. The scope of the refugees in this study refers to the meaning of refugees in the Presidential Regulation No. 125/2016, which includes asylum seekers.

\section{Method}

This study is a normative legal research, which is conducted based on library research by analyzing secondary data [4]. It uses three types of secondary data; primary legal materials (legislation), secondary legal materials (elucidating primary legal materials), and tertiary legal materials (supporting primary and secondary legal materials) [5]. The primary legal materials referred to in this study are the Civil Code, the Law No. 6/2011 on Immigration (Immigration Law), the Law No. 13/2003 on Manpower (Manpower Law), and the Presidential Regulation No. 125/2016. In the meantime, the secondary legal materials include books and journals, while the tertiary legal materials are dictionaries. The data, in turn, are analyzed using descriptive qualitative method by accurately describing a particular situation or phenomenon [6] and understanding it in depth [7]. 


\section{Result and Disscusion}

\section{1 Conditions of Refugees in Indonesia}

According to UNHCR, refugees are any person due to reasonable fears; grounds of persecution including race, religion, nationality, and membership of certain social groups and political parties, outside their country of nationality and unwillingness to get protection from their home country. This definition refers to the 1951 Convention on the Status of Refugees. Here, UNHCR distinguishes refugees from asylum seekers. Asylum seekers are those who request to become refugees, but their request is being considered [8]. As a non-state party to the 1951 Refugee Convention, Indonesia has its own rules on the scope of refugees, including asylum seekers (The Presidential Regulation No. 125/2016, Article 1 Paragraph 1).

The data from UNHCR Indonesia mentions the number of refugees and asylum seekers in the country is about 13.657 people (December 2019); 13.900 people (December 2018); 13.840 people (December 2017); and 14.405 people (December 2016) respectively. On average, the number of Indonesian refugees ranged from 14,000 people in the last 4 years. If compared with some countries in Southeast Asia, such number is not too large. The number of refugees in Malaysia alone, for example, reaches 238.615 people and Thailand 114.896 people respectively [9]. More than half of the refugees are from Afghanistan, Somalia and Iraq (2016). In Indonesia, they are distributed in different places including Jakarta, Medan, Pekanbaru, Batam, Semarang, Surabaya, Pontianak, Balikpapan, Manado, Denpasar, Kupang, and Makassar. Their presence takes in 4 locations; Immigration Detention Center (Rumah Detensi Imigrasi/Rudenim), Immigration Office (Kantor Imigrasi/Kanin), community house and independent living (independent immigrant). Nevertheless, the smallest number of refugees does not reduce the international pressure on Indonesia to ratify the 1951 Refugee Convention.

The survey conducted by the Sandya Institute to $16 \%$ of refugees in Indonesia shows the level of refugee educational background is dominated by Junior High level with $41 \%$ (not passing), Junior High School Graduates with $8.3 \%$, Undergraduate level with $7.3 \%$ and post graduate educational background with $4.6 \%$ respectively [10]. In other words, the majority of their educational background is Junior High School level. This case is similar with Indonesian workers who are mostly vocational and high school graduates and even below the level and dominate the number of unemployed in Indonesia per August 2019 [11]. Consequently, if the refugees are allowed to work, it is certainly a threat to the local workers. This is the reason why the government makes a policy on banning the refugees from working.

However, based on their professional background and education, the majority of the refugees have jobs in their home countries; community, social and personal services sector with $15.6 \%$, retail and wholesale trade sector including restaurants and hotels with $11.4 \%$, and construction and agriculture sectors $11 \%$ each respectively. The remaining sectors (transportation, storage, communication, mining, manufacturing, finance, insurance and real estate, electricity, gas and water) represent $12.2 \%$ of the remaining percentages [12]. Here, the refugees who do not work are students, about $25 \%$, and other groups are unemployed. About $13.5 \%$ of the respondents do not mention certain employment sectors.

The survey says the majority of refugees have jobs in their country of origin. However, upon their arrival in Indonesia, their activities are very limited because they could not work like the locals. To meet their daily needs, they (excluding asylum seekers) depend on the assistance or allowance provided by the international organization for refugees (International Organization 
for Migration/IOM) and a number of other donor organizations. They do not regularly receive such assistance considering various organizations provide it depending on the countries of the donor. In 2018, for example, IOM announced it was reducing assistance to refugees due to aid commitment from Australia.

In the meantime, the Indonesian government itself does not have a special budget for refugees, all assistance is voluntary. This happens because the Immigration Law, as the legal basis for foreigners in Indonesia, does not regulate refugee fund. Although the Presidential Regulation No. 125/2016 is issued, the handling of refugees is left to each local government.

The lack of assistance in a way most refugees are still in a condition capable of working certainly encourages them to find ways to meet their living needs, one of which is finding a job. The main purpose of working is to get income to meet basic needs. In addition, working offers a sense of security and satisfaction and becomes a means of self-actualization [13]. Most importantly, it can make a person realize his/her sense of humanity [14]. These purposes are very important for refugees as various restrictions imposed by the country will distance them from social life. Here, a condition without having a job is a threat to one's sense of humanity [15]. No wonder if social issues such as fights that have led to the deaths of a number of refugees are rife in refugee camps. It has happened in North Sumatra [16]. In February 2019, a number of refugees made suicide attempts, hunger strikes and self-immolation in the Menado detention center [17].

Conflicts with the surrounding communities also often occur due to the rejection to refugee camps in Kalideres for health and safety reasons [18]. The communities in Puncak area are reportedly uneasy with the refugees who work illegally; working as a barber and opening illegal businesses such as selling bread, among others [19]. In fact, the number of unemployed among the local population is still high in the area.

A number of refugees also commit some criminal acts such as prostitution, narcotics trafficking and human trafficking. In 2019, the Police arrested a number of child refugees involved in prostitution [20]. Concerning narcotics, the Indonesian National Narcotics Agency (BNN) has found a khat field in Bogor and Interpol has issued a detention warrant to one of the refugees named Said Mir Bahrami who was involved in buying and selling drugs and human smuggling [21].

\subsection{The Right to Work for Refugees in Indonesia}

The right to work for refugees is regulated in the 1951 Refugee Convention. However, Indonesia is not one of the countries signing and ratifying the convention. This means it does not have the obligation to follow all the regulations mentioned in the convention, including giving opportunities to refugees to work. To protect the national interests, Indonesia has banned refugees from working. The national interest here is the high unemployment rate in Indonesia.

In addition, the Immigration Law, in conjunction with the Manpower Law, does not allow foreigners to work without permission. Those who can work in Indonesia are foreign nationals holding a work visa or referred to as foreign workers (Article 1 Paragraph 13 of the Manpower Law). In another word, refugees are clearly not included as foreign workers as they do not hold visas.

The refugee employment prohibition is explicitly mentioned in the Director General of Immigration Regulation No. IM.0352.GR.02.07. on the Handling of Illegal Immigrant Claiming to be Asylum Seeker or Refugee on April 19, 2016. According to the Regulation, refugees are not allowed to find a job and carry out activities related to earning wages. Based on Article 1 Paragraph 3 of the Manpower Law which regulates the definition of workers or laborers, the compensation received by a worker is wages or other forms of compensation. This 
means there is a loophole the refugees can use to be able to work; as long as they are not paid in the form of wages and the process of finding a job is not their initiative.

Besides wages, workers can get rewards in other forms such as salary, commission, honorarium and compensation. Salary, for instance, is a payment for services performed by employees who have a position such as a manager [22]. In the meantime, commissions are rewards paid for a given service [23], while honorarium is payment for services and development activities in the government. At last, compensation is anything received in physical or non-physical forms, money or goods, both directly and indirectly [24].

Another loophole is this Law is perceived to only set employment in formal sector. This implies a room for refugees to work in the informal sector. Employment in the informal sector is a type of work where responsibility is individual, not incorporated and only based on an agreement [25]. Becak drivers, street vendors, builders, carpenters, tailors, and shoeshiners are the examples. One of the advantages of this employment is that it is more flexible as it is not bound by rules and taxes. However, it does not have legal protection for both the employees and the employers.

The informal employment status with agreement is actually under protection considering it is based on the principle of freedom of contract (Article 1338 of the Civil Code). Although considered in the informal sector, it will always be protected as long as it meets the legal requirements (Article 1320 of the Civil Code). However, the employment agreement involving refugees violates one of the legal conditions, a permission granted by the statutory regulations. To that end, the regulations in the Civil Code cannot be used as a protection for informal employment agreements involving refugees.

The lack of legal protection for refugees working in the informal sector has taken its toll. In 2016, for example, a number of refugees who worked as barbers in a number of salons in the Puncak Area, Bogor, were arrested for violating work restrictions stipulated in the Director General of Immigration Regulation No. IM. 0352.GR.02.07. According to Article 185, paragraph 1 jo. Article 42, paragraph 1 of the Manpower Law, salon owners who have employed them may also be subject to imprisonment and/or fines.

Another thing the refugees can use as a loophole is apprenticeship regulation. Apprenticeship is a work training system organized in an integrated manner in training institutions by working directly under the guidance and supervision of instructors or more experienced workers, in the process of producing goods and/or services in companies, for example (Article 1 Paragraph 11 of the Manpower Law). Through the apprenticeship, besides improving their skills and expertise, the refugees can earn money. The apprenticeship program for refugees has been undertaken by a number of parties such as the Geutanyao Foundation (Aceh), which attempts to employ a number of refugees in a workshop [26]. However, due to the high unemployment rate of Vocational School graduates, such apprenticeship is prioritized for them. In fact, the absence of particular regulation for handling foreign nationals causes the Department of Manpower (Dinas Tenaga Kerja/Disnaker) to tend to use the foreign worker provisions for apprentices who have already got a permit. Therefore, if companies are willing to accept refugees for apprenticeship, they must run it informally, behind the Manpower Officer.

In addition, partnership can also be used by refugees to work. It is a cooperation built as partners or coworkers [27]. The concept of partnership with refugees has been applied by several parties. The locals, for example, initiate to lend their land to the refugees. In return, they need to give some of the yields to them [28].

Basically, the three concepts do not have clear legal protection for refugees, employers, and facilitating organizations. The government may ban them from using the existing 
instruments or tools at any time. To this end, the regulation that clearly stipulates the rights to work for refugees is necessary.

\subsection{Solution to Arranging the Right to Work for Refugees}

At a number of national and international forums, representatives from the government and the Parliament have stated that they do not support the ratification of the 1951 Convention for various reasons; encouraging an increase in the number of refugees in Indonesia, reducing employment opportunities for the locals and the potential for conflict, among others. Hence, the future solution to deal with the refugee employment is to set a number of regulations. The regulations such as the Presidential and the Directorate General Regulations are inadequate considering they are in contrast to the Immigration Law and the Manpower Law which set criminal sanctions for any party that employs other people who live in Indonesia illegally or without permission. Here, the Immigration Law needs to be amended by adding a scheme of providing refugee employment. In addition, the lex specialists in employment sector, the Manpower Law in this case, needs to set regulations for refugees. The refugees are different from Foreign Workers as the Labor Law prohibits individuals from employing them, limit the types of work they can do and is obliged to repatriate them to their home countries. In the end, the regulations or provisions mentioned in the Immigration Law needs to synchronize with the ones set in the Manpower Law.

However, in granting the rights to work for refugees, some restrictions are also needed. They, for example, can only work in positions and fields that are still scarce in Indonesia. Additionally, the apprenticeship concept can also be applied as it basically provides education and training for them. Offering jobs for the locals is still a priority. At last, the partnership concept is also possible as it is more flexible and mutually beneficial.

\section{Conclusion}

Indonesia has not ratified the 1951 convention, in which one of its contents is requiring countries party to provide employment opportunities for refugees. In addition, refugees also do not meet the criteria of foreigners who can have a job as mentioned in the Immigration Law and the Manpower Law. Consequently, they are banned from working in Indonesia. The refugee employment prohibition causes their activities to be very limited. They also experience economic limitations due to lack of assistance. Such conditions encourage them to find loopholes in order to be able to work; with informal employment scheme, apprenticeship and partnership, among others. Basically, these loopholes are very risky for both refugees and employers due to the lack of legal protection. In addition, a number of refugees commit illegal work such as prostitution and drug dealing. The refugee employment prohibition, on one hand, aims at protecting national interests due to the lack of employment opportunities for the locals. However, on the other hand, this ban poses a threat to the national interest as some refugees commit illegal work. To this end, they should be given the opportunity to work, but with restrictions. They, for example, can only work in the sectors which are undesirable in Indonesia. This will not interfere with the employment opportunities for the locals. More importantly, the limited employment opportunities need to be regulated in the Immigration Law and the Manpower Law. Meanwhile the ratification seems very difficult to achieve due to the lack of support from lawmakers, the government and the parliament. 


\section{References}

[1] Kemlu. "Indonesia Tegaskan Komitmen untuk Tata Kelola Pengungsi Global". 17 Desember 2019.

[2] Sirait, Kevin Ronaldo, et. al. "Usaha Mendapatkan Pengakuan Internasional: Kebijakan Indonesia Mengeluarkan Peraturan Presiden 125/2016 dalam Menangani Isu Pengungsi”. Indonesian Perspective, Vol. 4 No. 2. pp. 152 (2019).

[3] Merdeka.com. "36 Pencari Suaka Bermasalah Ditempatkan di Rudenim Makassar", 4 September 2019.

[4]Soekanto, Soerjono \& Sri Mahmuji. "Penelitian Hukum Normatif". Jakarta: Rajawali Pers. pp.12 (2003)

[5] Ibid. pp.13.

[6]Mahmudji, Sri et al. "Metode Penelitian dan Penulisan Hukum". Fakultas Hukum UI. pp.4 (2005).

[7]Erwinsyahbana, Tengku \& Ramlan."Penelitian Kualitatif Bidang Ilmu Hukum dalam Prespektif Filsafat Konstruktivis“.pp. 5 (2018).

[8] UNHCR, https://www.unhcr.org/id/unhcr-di-indonesia.

[9] UNHCR, "Keberadaan Pengungsi dan Pencari Suaka”. Makalah. Jakarta: DPR, 27 Maret 2018.

[10] LoCastro, Matthew et. al. "Menjelaskan Potensi Ekonomi Komunitas Pengungsi Indonesia:Survei mengenai Karakteristik Ketenagakerjaan dan Penghidupan“. Makalah. Jakarta: Sandya Institute. pp.22 (2019).

[11] BPS. "Berita Resmi Statistik", 5 November 2019.

[12] LoCastro, Matthew et al., Op. Cit., pp.18-19.

[13] Puspitasari, Dewi \& Setia Asyanti. "Faktor yang Paling Berpengaruh terhadap Komitmen Kerja Perawat Panti Wreda di Surakarta”. Undip Journal of Psychology. Vol.9 No. 1. pp.57 (2011).

[14] Jaenudin, Enjang. "Makna Kerja Bagi Guru Khidmah Di Pondok Pesantren Al Luqmaniyah Yogyakarta“. Skripsi. Yogyakarta: Universitas Mercu Buana. pp.7 (2018)

[15] Amelia, Anggita. "5 Hal ini yang Memicu Rasa Kemanusiaan Seseorang Kian Memudar", 20 Maret 2020.

[16] Kadarudin et al "The Situation of international Refugee in Indonesia: A Legal Perpective",Veritas et Justitia, Vol. 4 No.1. pp. 18-19 (2018).

[17] Raharjo, Budi. "Dari Afghanistan untuk Semangkuk Bakso", 5 Juli 2019.

[18] Anugrahadi, Ady. "Warga Menolak Pengungsian di Kalideres, Ini Kata Pencari Suaka", 14 Juli 2019.

[19] Missbach, Antje. "Troubled Transit: Politik Indonesia Bagi Para Pencari Suaka”, Jakarta: Yayasan Pustaka Obor Indonesia. pp.128-129 (2016).

[20] Tempo.co. "Prostitusi Remaja Pencari Suaka, Komnas Anak: Ada yang Fasilitasi”, 21 Agustus 2019.

[21] Missbach, Antje. Op. Cit. pp.129-130.

[22]. Mulyadi. "Sistem Akuntansi”. Yogyakarta: Sekolah Tinggi Ilmu Ekonomi YKPN. pp.377 (2001).

[23] KBBI.

[24] Online-pajak.

[25] Reaktor.co.id. "Pengertian Pekerja Formal 'White Collar' dan Pekerja Informal 'Blue Collar", 12 Agustus 2019.

[26] Rinn, Sherr. "Mencari Pekerjaan untuk Pengungsi”, 13 Desember 2016.

[27] KBBI.

[28] Rinn, Sherr. Loc. Cit. 